University of Montana

ScholarWorks at University of Montana

$10-2000$

\title{
Facilitation May Buffer Competitive Effects: Indirect and Diffuse Interactions Among Salt Marsh Plants
}

\author{
Ragan M. Callaway \\ University of Montana - Missoula, Ray.Callaway@mso.umt.edu \\ Steven C. Pennings
}

Follow this and additional works at: https://scholarworks.umt.edu/biosci_pubs

Part of the Biology Commons

Let us know how access to this document benefits you.

\section{Recommended Citation \\ Callaway, Ragan M. and Pennings, Steven C., "Facilitation May Buffer Competitive Effects: Indirect and Diffuse Interactions Among Salt Marsh Plants" (2000). Biological Sciences Faculty Publications. 209. https://scholarworks.umt.edu/biosci_pubs/209}

This Article is brought to you for free and open access by the Biological Sciences at ScholarWorks at University of Montana. It has been accepted for inclusion in Biological Sciences Faculty Publications by an authorized administrator of ScholarWorks at University of Montana. For more information, please contact scholarworks@mso.umt.edu. 


\section{Facilitation May Buffer Competitive Effects: Indirect and Diffuse Interactions among Salt Marsh Plants}

\author{
Ragan M. Callaway, ${ }^{1, *}$ and Steven C. Pennings ${ }^{2}$ \\ 1. Division of Biological Sciences, University of Montana, \\ Missoula, Montana 59812; \\ 2. University of Georgia Marine Institute, Sapelo Island, Georgia \\ 31327
}

Submitted October 15, 1999; Accepted May 30, 2000 species interact within communities. Within a trophic level, additional species can alter pairwise interactions via direct and indirect pathways (Lawlor 1979; Stone and Roberts 1991; Miller 1994; Wooton 1994) and through the cumulative, "diffuse" effects of many direct effects acting on a single species (Davidson 1980; Wilson and Keddy 1986a, 1986b; Vandermeer 1990). For example, Levine (1976) demonstrated that the addition of a third competitor to a model of two competing species could change the cumulative effect of a species from competitive to facilitative because of the suppression of a shared competitor. Similarly, models of interactions among invading exotic and native species have suggested that natives may be completely displaced in pairwise interactions but can coexist with exotics in diverse communities, apparently because of the greater number of indirect interactions (Case 1991). Despite the potential importance of indirect interactions in plant communities, only a few experiments have attempted to demonstrate the existence of interactions in which "a competitor's enemy is a friend" (Wilson and Keddy 1986a; Miller 1994; Levine 1999).

Direct interactions among plants can also be facilitative (Callaway 1995), and although positive interactions have been demonstrated in many experiments, little is known about indirect interactions involving species with facilitative effects. In the upper zones of coastal salt marshes in southern California, the two dominant perennial species appear to have strikingly opposite effects on most co-occurring winter annual species. Arthrocnemum subterminale, a succulent subshrub, has been shown to facilitate two annual species, Parapholis incurva and Lasthenia glabrata (Callaway 1994); whereas Monanthecloe littoralis, a clonal grass, appears to eliminate virtually all annuals by establishing a thick vegetative mat (R. M. Callaway and S. C. Pennings, personal observation). Furthermore, long-term monitoring (see "Results") at our study site indicates that Monanthechloe is increasing in abundance and displacing Arthrocnemum and winter annual species. Together, these patterns suggest the potential for unusual indirect interactions. We hypothesized that Monanthechloe might directly outcompete annual
Am. Nat. 2000. Vol. 156, pp. 416-424. (c) 2000 by The University of Chicago. 0003-0147/2000/15604-0007\$03.00. All rights reserved. 


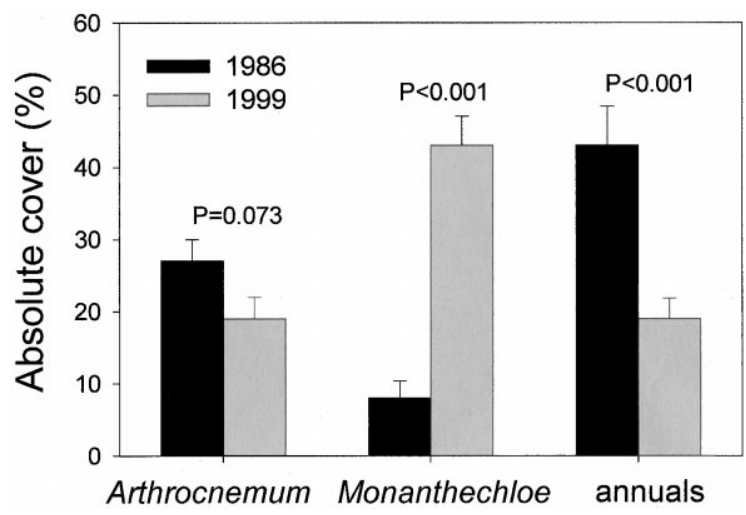

Figure 1: Percentage cover of Monanthechloe littoralis, Arthrocnemum subterminale, and winter annual species in permanent plots in Carpinteria Salt Marsh, California, in 1986 and 1999. Bars represent 1 SE.

species but that the positive effect of Arthrocnemum might buffer annual species from the full negative effect of Monanthechloe. We tested these hypotheses in four ways: first, by correlating changes in the relative abundance of Monanthechloe with the abundance of other species over the past $13 \mathrm{yr}$, second, by measuring patterns of abundance of annual species associated with Arthrocnemum in the presence and in the absence of Monanthechloe, third, by conducting field experiments in which we measured the direct effects of the perennials on each other and on annual species and a perennial herb, and finally, by conducting field experiments in which we measured the effects of Monanthechloe on other species in the presence and in the absence of Arthrocnemum.

\section{Study Site}

We conducted our study in the upper "transition zone" at the Carpinteria Salt Marsh Reserve $\left(34^{\circ} 24^{\prime} \mathrm{N}, 119^{\circ} 31^{\prime} \mathrm{W}\right)$, approximately $15 \mathrm{~km}$ south of Santa Barbara, California. This site was described extensively in Ferren (1985), Callaway et al. (1990), and Pennings and Callaway (1992, 1996), and direct interactions among species in the transition zone have been examined in Callaway (1994). The dominant perennial species in the transition zone, approximately 0.4-0.6-m elevation above mean high high water, are the small shrub Arthrocnemum subterminale (Parish) Standl. and the highly rhizomatous, mat-forming Monanthlechloe littoralis. Winter annual species are distributed along an elevation-and-salinity gradient and include Spergularia marina, Parapholis incurva, Hutchinsia procumbens, Lasthenia glabrata, and Juncus bufonius (nomenclature follows Ferren 1985). The relative abundance of these species and their position on the elevation gradient varies substantially among years, at least partly due to variation in precipitation (Callaway and Sabraw 1994).

\section{Methods}

To document the natural dynamics of species in the upper marsh, we quantified the absolute cover of Arthrocnemum, Monanthechloe, and winter annuals in 59 permanent plots in 1986 and 1999. We also correlated the change of Monanthechloe absolute cover with the change of Arthrocnemum cover and the percentage change of cover of all annual species combined in each plot. For simplicity, and because of the year-to-year variation in the relative abundances of different annual species among years and with
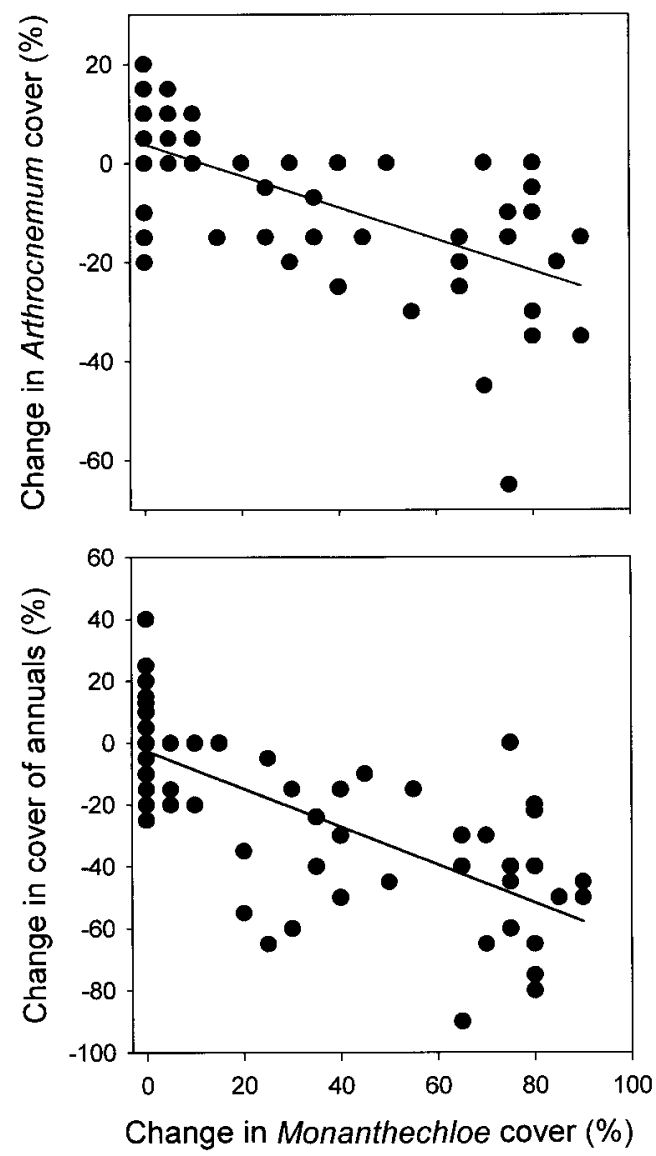

Figure 2: Regression relationship between the change in percentage cover of Monanthechloe littoralis and the change in percentage cover of $\mathrm{Ar}$ throcnemum littoralis and annual species in Carpinteria Salt Marsh, California. For Arthrocnemum, $y=3.80+x(-0.32), r^{2}=0.39, P<.01$; for annuals, $y=-2.53+x(-0.61), r^{2}=0.49, P<.01$. 


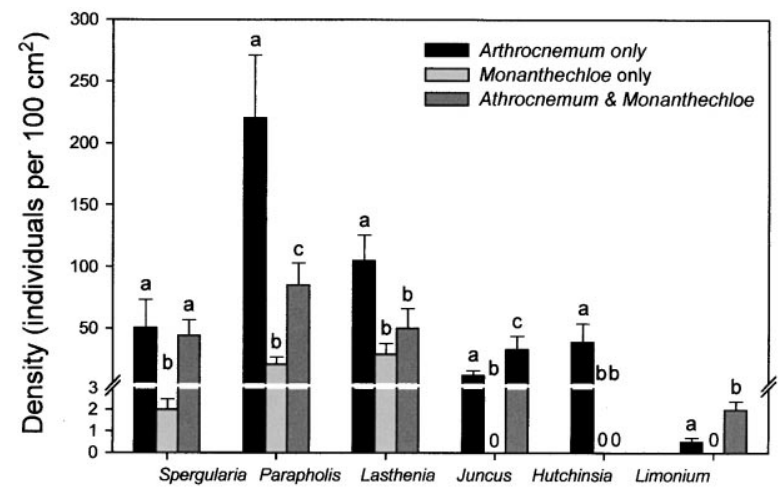

Figure 3: Densities of annual species in plots containing the perennials Monanthechloe littoralis, Arthrocnemum subterminale, or both in Carpinteria Salt Marsh, California. Bars represent $1 \mathrm{SE}$, and shared letters for a species indicate no significant difference between means (ANOVA, postANOVA Tukey, $P<.05)$.

elevation, all annual species were combined for these analyses.

To document current spatial associations among species, we sampled the density of all annual species and new recruits of the perennial herb Limonium in May 1998 in $100-\mathrm{cm}^{2}$ quadrats in patches with the perennial community represented by only Arthrocnemum $(n=20)$, only Monanthechloe $(n=20)$, and both Arthrocnemum and Monanthechloe $(n=20)$. In patches dominated by Monanthechloe, Monanthechloe was present at $100 \%$ cover and with a mat $2-3 \mathrm{~cm}$ deep. Plots were chosen by randomly locating a point on transects and then moving in a random direction until one sample of each of the three different patch types were encountered. For each individual species, and all annual species combined, one-way ANOVAs and post-ANOVA Tukey tests were used to compare densities among patch types. All data for individual species were log transformed to improve normality.

In May 1997, we removed either Monanthechloe or Arthrocnemum from patches in which either one or the other occurred, avoiding patches containing both perennial species together, in order to examine the direct effects of the two large perennials on the annual species and on $\mathrm{Li}$ monium. Because site effects might confound the effects of the perennials, we chose patches that were as intermixed as possible. At the beginning of the experiment, annuals and Limonium were present in plots with only Arthrocnemum but not in plots with Monanthechloe. For each perennial species, we established $10400-\mathrm{cm}^{2}$ removal plots and 10 control plots. In May 1998, we counted all individuals of all annual species in the center $100 \mathrm{~cm}^{2}$ of each plot. Limonium densities were sampled in June 1999 in the entire $400-\mathrm{cm}^{2}$ plot because densities were much lower. Effects were tested using a one-way ANOVA (SPSS 1997) for each of the four most abundant annual species, Juncus, Parapholis, Lasthenia, and Spergularia, and the perennial herb Limonium in each removal treatment. Data for other annual species were not analyzed because they were present in only a small fraction of the plots.

To examine the interactive effects of Monanthechloe and Arthrocnemum on annual species and Limonium, we established a second experiment in May 1997. Before manipulation, each $100-\mathrm{cm}^{2}$ plot contained a single $A r$ throcnemum individual and 100\% cover of Monanthechloe forming a 2-4-cm deep mat. We established the four following treatments: removal of Monanthechloe, removal of Arthrocnemum, removal of both perennials, and both perennials left intact ( $n=10$ for each). No annuals or Limonium were present in plots at the beginning of the experiment. We counted all individuals of all annual species in May 1998 and Limonium recruits in June 1999. We measured recruits of the perennial Limonium after 2 yr because it recruited much more slowly than the annuals. We analyzed the results of this experiment using a two-way ANOVA for each of the four annual species and Limonium in which the presence or absence of each perennial was considered as a main effect. We also used these treatments to assess the effect of Monanthechloe on Arthrocnemum. At the time that the experiment was established, a $50 \times 50-\mathrm{cm}$ grid subdivided into 100 $5 \times 5$-cm cells was placed over the central Arthrocnemum individual and the number of cells occupied by Arthrocnemum was counted. In May 1998, cells were counted again and the change in number of cells occupied was compared among Monanthechloe removal treatments separately using a one-way ANOVA. In 10 other plots, we measured the effect of Arthrocnemum on Monanthechloe. We chose plots in which Arthrocnemum occurred at 90\%-100\% cover and Monanthechloe occurred at $<50 \%$ cover. In 10 plots, we removed Arthrocnemum and compared changes in the cover of Monanthechloe to that in the 10 control plots. Measurements of cover and analyses were the same as used for examining the effects of Monanthechloe on Arthrocnemum.

\section{Results}

Monanthechloe appeared to be expanding in the marsh at the expense of all of the other species we studied. In 59 plots on permanent transects, Monanthechloe increased from $8 \%$ cover in 1986 to $43 \%$ in 1999 (fig. 1). During the same time period, Arthrocnemum decreased from $27 \%$ to $19 \%$, and total annual cover decreased from $43 \%$ to $19 \%$. Within individual $0.125-\mathrm{m}^{2}$ plots, increases in Mon- 

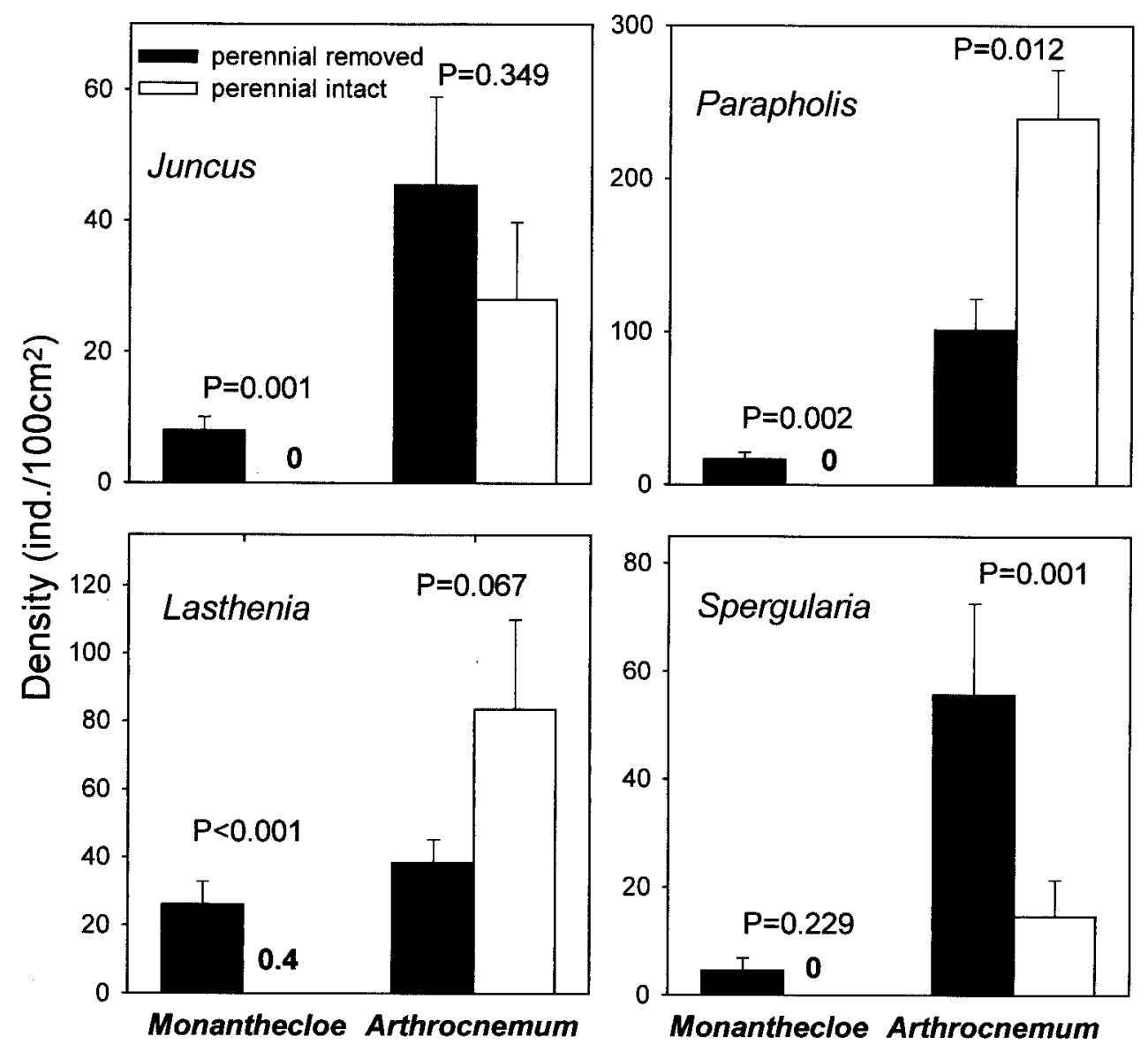

Figure 4: Densities of the four most common annual species in response to the removal of Monanthechloe littoralis or Arthrocnemum subterminale at Carpinteria Salt Marsh, California. Bars represent 1 SE. For the Monanthechloe only and the Monanthechloe plus Arthrocnemum plots, the cover of Monanthechloe was $100 \%$, and the depth of the vegetative mat was the same $(2.7 \pm 0.4 \mathrm{~cm}$ and $2.8 \pm 0.6 \mathrm{~cm}$, respectively).

anthechloe abundance were significantly correlated with decreases in Arthrocnemum and annual cover (fig. 2).

Winter annual species coexisted with Arthrocnemum but not with Monanthechloe, and the presence of Arthrocnemum in patches of Monanthechloe was correlated with high abundances of annual species. In 1998, most annual species were significantly $(P=.061$ for Spergularia) more common when only Arthrocnemum was present than when only Monanthechloe was present (fig. 3). Even though the cover and thickness of Monanthechloe were similar in plots with Monanthechloe alone and plots with Monanthechloe and Arthrocnemum together, the densities of Spergularia, Parapholis, and Juncus were significantly higher in patches of Monanthechloe when Arthrocnemum was also present than when only Monanthechloe was present. Limonium was absent in plots with only Monanthechloe, uncommon in plots with only Arthrocnemum $(0.5 \pm 0.2$ individuals $/ 100$ $\mathrm{cm}^{2}$ ), and most abundant where both Monanthechloe and
Arthrocnemum were present (fig. $3 ; 2.0 \pm 0.4$ individuals/ $100 \mathrm{~cm}^{2}$; ANOVA, $\left.\mathrm{df}=2,56, P<.001\right)$. The difference between the latter two sites was significant (Tukey, $P<$ $.001)$.

In single-species removal experiments, the direct effects of Monanthechloe on annuals and Limonium were consistently negative (fig. 4; table 1). One season after treatments were established, annuals were virtually absent in Monanthechloe patches but present in Monanthechloe removal plots at densities ranging from 3 to 28 individuals $/ 100$ $\mathrm{cm}^{2}$. Two seasons after treatments were established, no Limonium occurred in the presence of Monanthechloe, whereas Limonium density was $3.6 \pm 1.7 / 400 \mathrm{~cm}^{2}$ when Monanthechloe was removed. The direct effects of Arthrocnemum ranged from strongly negative on Spergularia to strongly facilitative on Parapholis and Lasthenia. However, all four annual species were much more abundant in both Arthrocnemum-only treatments than in the treatment 
Table 1: ANOVA table for the direct effects of Monanthechloe littoralis and Arthrocnemum subterminale on the density of winter annuals

\begin{tabular}{lrc}
\hline Species & \multicolumn{1}{c}{$F$} & $P$ \\
\hline Monanthechloe removal: & & \\
Juncus balticus & 14.40 & $.001^{\mathrm{a}}$ \\
Parapholis incurva & 12.72 & $.002^{\mathrm{a}}$ \\
Lasthenia glabrata & 14.42 & $.001^{\mathrm{a}}$ \\
Spergularia marina & 1.55 & .229 \\
Arthrocnemum removal: & & \\
Juncus balticus & .93 & .349 \\
Parapholis incurva & 34.71 & $<.001^{\mathrm{b}}$ \\
Lasthenia glabrata & 3.79 & $.067^{\mathrm{b}}$ \\
Spergularia marina & 5.11 & $.001^{\mathrm{a}}$ \\
\hline Note: For all species, df = 1, 19. & \\
' & \\
'Direction of effect is negative. &
\end{tabular}

where Monanthechloe was removed. Arthrocnemum had no significant direct effect on Limonium: Limonium density was $1.9 \pm 1.4 / 400 \mathrm{~cm}^{2}$ when Arthrocnemum was removed and $1.6 \pm 1.5 / 400 \mathrm{~cm}^{2}$ when it was present $(t$-test, $P>$ $.5)$. The magnitude of the effects of Monanthechloe and Arthrocnemum may not be directly comparable within this experiment because of the different populations of annuals present when removal was established. At the time experiments were established, no annuals were present in the plots with Monanthechloe, but annuals were abundant in the plots with Arthrocnemum. Therefore, Monanthechloe plots probably did not have large seed banks or seed inputs, compared to Arthrocnemum plots, at the beginning of the experiment.

The direct effect of Monanthechloe on Arthrocnemum was also negative (fig. 5). Arthrocnemum cover increased $4 \% \pm 2 \%$ when Monanthechloe was removed but decreased by $3 \% \pm 1 \%$ when Monanthechloe was not present $(F=13.78, \mathrm{df}=1,19, P=.002)$. Arthrocnemum also had significant competitive effects on Monanthechloe (fig. 5; $F=6.90, \mathrm{df}=1,19, P=.014$ ), but the cover of Monanthechloe increased significantly whether Arthrocnemum was present.

Field experiments indicated that Arthrocnemum reduced the competitive effects of Monanthechloe, corroborating the spatial patterns described in figure 3. In the factorial experiment designed to examine the combined and indirect effects of the large perennials, competition from Monanthechloe was by far the strongest overall effect and was significant for each of the annual species and for $L i$ monium (figs. 6, 7; table 2). When Arthrocnemum was left intact but Monanthechloe was removed, the density of Parapholis was over five times higher than when both perennials were removed. In intact patches of Monanthechloe,
Parapholis survived only when Arthrocnemum was present. Similar patterns were observed for Lasthenia and Juncus, but the direct effects of Arthrocnemum were not as strong. The most striking indirect effects in the factorial field experiment occurred for Spergularia and Limonium. In the absence of Monanthechloe, Spergularia was much more common when Arthrocnemum was removed, indicating a competitive effect of Arthrocnemum. But when the dominant competitor Monanthechloe was present, Arthrocnemum strongly facilitated Spergularia. Limonium was indifferent to the presence of Arthrocnemum when Monanthechloe was absent, but in the presence of Monanthechloe, Limonium recruits were only found in plots in which Arthrocnemum was also present.

\section{Discussion}

Strong direct competition, facilitation, and indirect facilitation occurred among plant species in the upper marsh at Carpinteria. Monanthechloe increased in abundance in the upper margins of Carpinteria Salt Marsh and displaced annuals and Limonium; however, Arthrocnemum buffered the competitive effects of Monanthechloe on several of these species. In patches of Monanthechloe, more annuals occurred with Arthrocnemum than in its absence (fig. 3). In the presence of Monanthechloe in field experiments, Parapholis, Lasthenia, Spergularia, and Limonium were more abundant with Arthrocnemum pre-

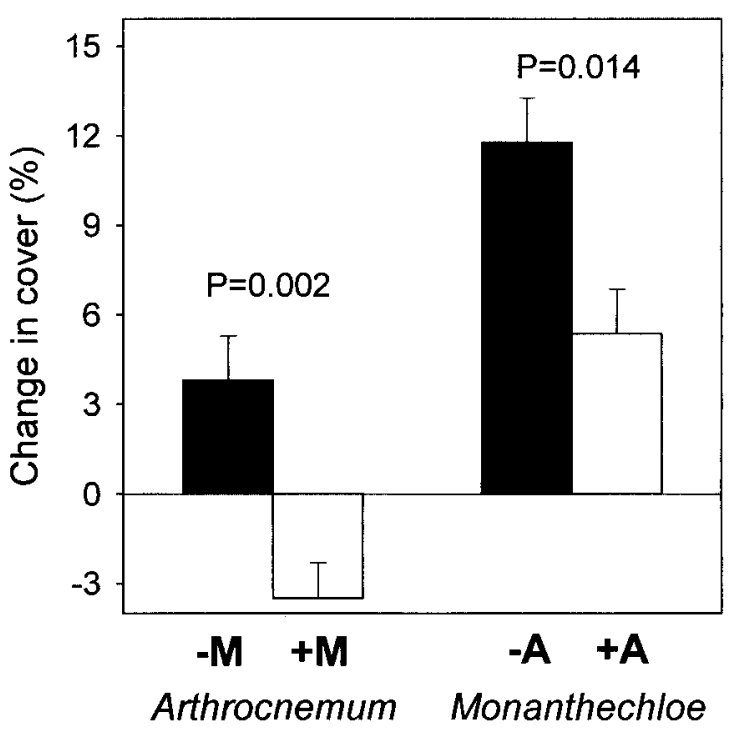

Figure 5: Change in cover of Monanthechloe littoralis and Arthrocnemum subterminale over one growing season in response to the removal of the other species. Bars represent 1 SE. 

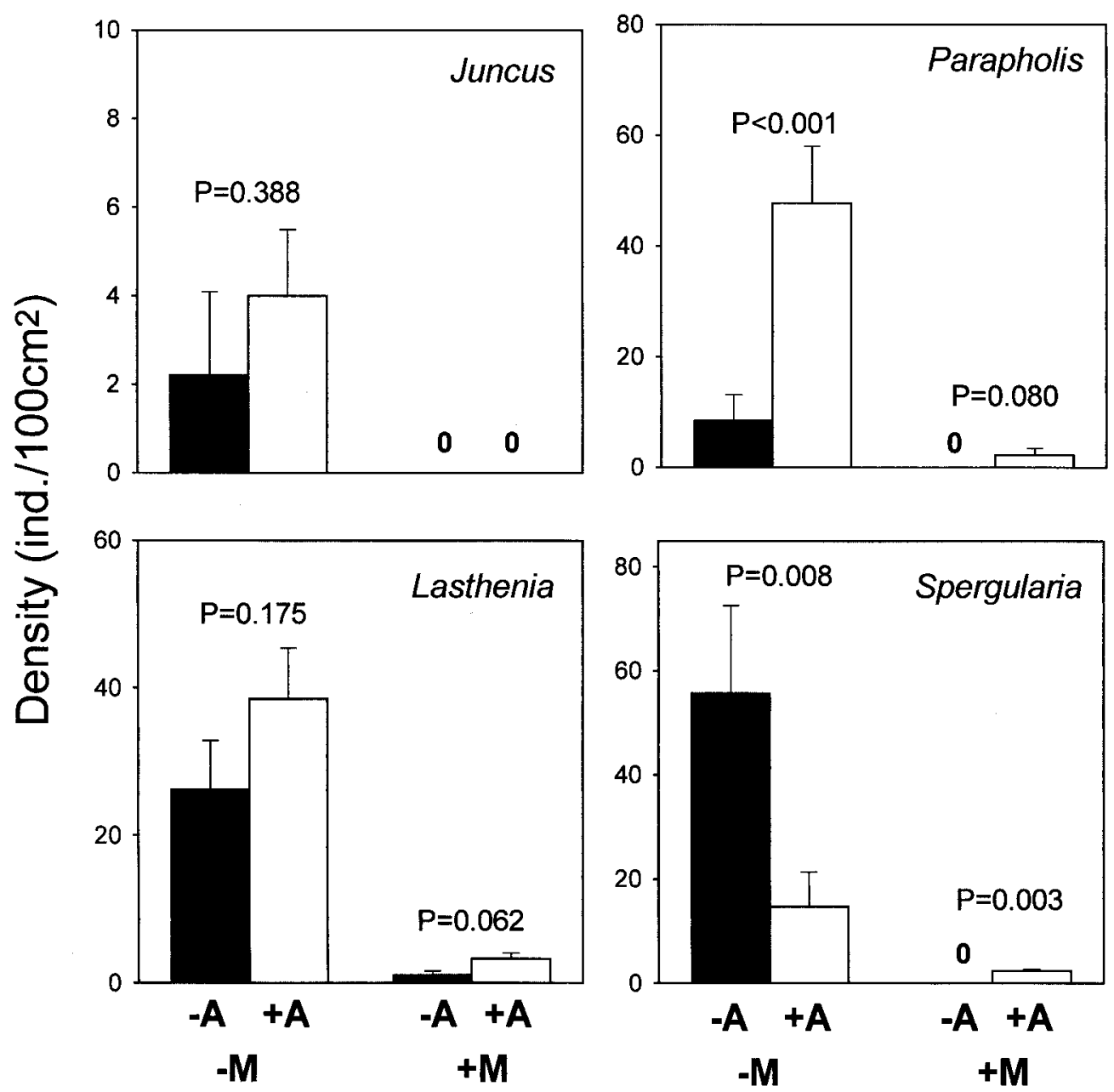

Figure 6: Densities of the four most common annual species after the factorial removal of Monanthechloe littoralis and Arthrocnemum subterminale at Carpinteria Salt Marsh, California. Bars represent 1 SE. See table 2 for results of the ANOVA.

sent than when it was removed (fig. 6). We suggest that there were two different types of indirect interactions that may explain our results. First, webs of indirect effects (sensu Lawlor 1979; Miller 1994; Wooton 1994) probably explain the results with Spergularia and Limonium. In the absence of Monanthechloe, Arthrocnemum competed with Spergularia and had no effect on Limonium, but in the presence of Monanthechloe, Arthrocnemum facilitated Spergularia and Limonium, probably because Arthrocnemum had a competitive effect on Monanthechloe. Second, "diffuse" interactions (sensu Wilson and Keddy 1986a) may best explain the effects of Arthrocnemum on Parapholis and Lasthenia (i.e., a direct positive effect of Arthrocnemum on these annual species canceling out a direct negative effect of Monanthechloe) because Arthrocnemum had positive effects on these species with or without Monanthechloe.
To our knowledge, there have been few experimental demonstrations of indirect effects among plants. Miller (1994) quantified direct and indirect effects among five old-field plant species and consistently found important indirect positive effects. Takahashi (1997) showed that indirect interactions were important for the regeneration of two subalpine conifer species. Levine (1999) demonstrated that Carex nudata, a riparian sedge, had a strong indirect effect on the liverwort Conocephalum conicum by reducing the abundance of Mimulus guttatus, a strong competitor of Conocephalum. Wilson and Keddy (1986a) manipulated direct effects among wetland plants and found indications of indirect effects. In nonexperimental studies, the results of Petranka and McPherson (1979) suggested that prairie shrubs facilitate tree species by allelopathically suppressing grasses. However, these studies all differed from ours in 


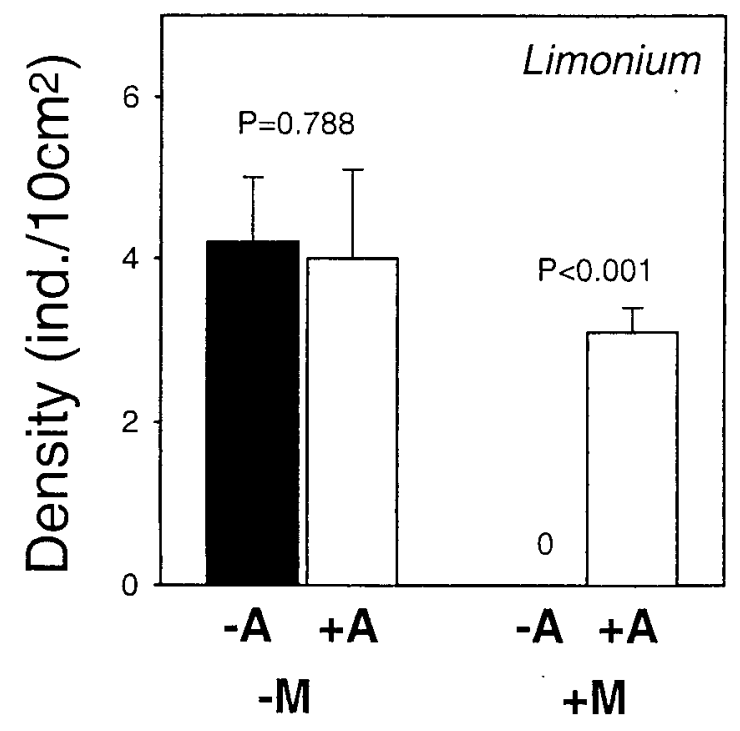

Figure 7: Density of Limonium californicum after the factorial removal of Monanthechloe littoralis and Arthrocnemum subterminale at Carpinteria Salt Marsh, California. Bars represent 1 SE.

that they only examined species with direct competitive effects.

The competitive effect of Monanthechloe on Arthrocnemum, Limonium, and all of the annual species was stronger and more consistent than the positive effects of Arthrocnemum on other species. However, weak or "feeble" indirect effects among consumers have been shown to have important overall effects in communities (Berlow 1999). The mechanisms by which Monanthechloe outcompetes annuals and Limonium are not known; however, heavy mats of Monanthechloe create very dense shade, around $0.5 \%-1 \%$ of ambient sunlight (data not presented). Correlative evidence suggests that Arthrocnemum may facilitate other species by decreasing soil salinity, moderate shading (ambient light is reduced by about 60\%), and increasing soil moisture (Callaway 1994). The direct effects of Arthrocnemum described here-facilitation of Parapholis and Lasthenia but competition with Spergularia-correspond to the findings of previous studies (Callaway 1994).

Bertness and Callaway (1994) hypothesized that positive interactions increased in importance with abiotic stress and low productivity. Wilson and Keddy (1986a, 1986b) estimated the strength of diffuse competition in a lake shoreline plant community by incorporating the number of neighbor species removed into the effect of neighbor removal. With this approach they showed that diffuse interactions were particularly strong when total plant biomass was high. In fact, when biomass was the lowest, target species were smaller in the absence of all neighbors than in their presence, indicating a cumulative facilitative diffuse effect. We found that the total removal of neighbors was never optimal for annual species or for Limonium. For every individual species, and for the analysis of all annual species together (table 2), the presence of Arthrocnemum after the removal of Monanthechloe resulted in higher abundances. In support of Wilson and Keddy $(1986 b)$, the transition zone of the marsh in which we worked is the zone of lowest biomass and productivity in the Carpinteria Salt Marsh (Pennings and Callaway 1992).

Our experiments were limited in that we did not quantify the effects of the annuals on the shrubs, which was primarily because the relative biomass of the shrubs was much higher. However, Pugnaire et al. (1996) and Moro et al. (1997) presented evidence that the effect of the understory herb Marrubium vulgare on the shrub Retama sphaerocarpa was positive and that the dense cover of understory herbs provided a ground cover to retain water. Holzapfel and Mahall (1999) demonstrated experimentally that winter annuals in the Mojave Desert had weak competitive effects on overstory Larrea tridentata shrubs.

We only removed the effects of the perennial canopies and did not manipulate root effects. However, root interactions among the species with which we worked appear to be relatively weak. Callaway (1994) conducted experiments in which canopies and roots were manipulated factorially. Canopy effects of Arthrocnemum were strong (negative for Spergularia and positive for Parapholis and Hutchinsia procumbens), but root effects were weak and significant only for Parapholis. In the experiments reported here, Arthrocnemum did not resprout after cutting, suggesting that roots had died, and invasion of Monanthechloe into plots from belowground was minimal. Therefore, we believe that we manipulated the most important mechanism of interaction between the perennials and annuals.

Indirect interactions involving consumers are well documented (Paine 1966; Lubchenco 1978; Kerfoot and Sih 1987; Connell 1990; Wooton 1994; Pennings and Callaway 1996), but progress toward understanding indirect interactions among competitors has been primarily theoretical until recently (MacArthur 1972; Pianka 1974; Buss and Jackson 1979; Case 1991; Stone and Roberts 1991; Miller and Travis 1996). Our results for Spergularia and Limonium corroborate the general conclusions of recent studies of indirect effects - that an enemy's enemy is a friend-but to our knowledge, no other studies have explicitly manipulated the combined effects of a species with strong competitive effects and another with strong facilitative effects. We found an array of direct and indirect responses, with significant direct competition and facilitation and significant indirect facilitation. Direct and indirect positive effects appeared to buffer the competitive effects of the 
Table 2: ANOVA table for the factorial effects of Monanthechloe and Arthrocnemum on winter annuals and the perennial Limonium californicum

\begin{tabular}{|c|c|c|c|c|}
\hline & $\mathrm{df}$ & MS & $F$ & $P$ \\
\hline \multicolumn{5}{|l|}{ Juncus bufonius: } \\
\hline Arthrocnemum effect & 1 & 15.6 & 1.02 & .320 \\
\hline Monanthechloe effect & 1 & 75.6 & 4.92 & $.033^{\mathrm{a}}$ \\
\hline Arthrocnemum $\times$ Monanthechloe & 1 & 3.0 & .20 & .660 \\
\hline Error & 36 & 15.4 & $\ldots$ & $\ldots$ \\
\hline \multicolumn{5}{|l|}{ Parapholis: } \\
\hline Arthrocnemum effect & 1 & 4,951 & 14.44 & $.001^{\mathrm{b}}$ \\
\hline Monanthechloe effect & 1 & 6,477 & 18.89 & $<.001^{\mathrm{a}}$ \\
\hline Arthrocnemum $\times$ Monanthechloe & 1 & 2,907 & 8.45 & .006 \\
\hline Error & 36 & 343 & $\ldots$ & $\ldots$ \\
\hline \multicolumn{5}{|l|}{ Lasthenia: } \\
\hline Arthrocnemum effect & 1 & 600 & 6.25 & $.017^{\mathrm{b}}$ \\
\hline Monanthechloe effect & 1 & 1,134 & 11.81 & $.002^{\mathrm{a}}$ \\
\hline Arthrocnemum $\times$ Monanthechloe & 1 & 156 & 1.62 & .211 \\
\hline Error & 36 & 96 & $\ldots$ & $\ldots$ \\
\hline \multicolumn{5}{|l|}{ Spergularia: } \\
\hline Arthrocnemum effect & 1 & 75.6 & 10.21 & $.003^{\mathrm{a}}$ \\
\hline Monanthechloe effect & 1 & 65.0 & 8.77 & $.005^{\mathrm{a}}$ \\
\hline Arthrocnemum $\times$ Monanthechloe & 1 & 65.0 & 8.77 & .005 \\
\hline Error & 36 & 12.1 & $\ldots$ & $\ldots$ \\
\hline \multicolumn{5}{|l|}{ Limonium: } \\
\hline Arthrocnemum effect & 1 & 10.0 & 14.63 & $<.001^{\mathrm{b}}$ \\
\hline Monanthechloe effect & 1 & 4.9 & 7.17 & $.011^{\mathrm{a}}$ \\
\hline Arthrocnemum $\times$ Monanthechloe & 1 & 8.1 & 11.85 & .001 \\
\hline Error & 36 & .7 & $\ldots$ & $\ldots$ \\
\hline \multicolumn{5}{|l|}{ Total annuals: } \\
\hline Arthrocnemum effect & 1 & 11,560 & 21.53 & $<.001^{\mathrm{b}}$ \\
\hline Monanthechloe effect & 1 & 13,176 & 24.54 & $<.001^{\mathrm{a}}$ \\
\hline Arthrocnemum $\times$ Monanthechloe & 1 & 3,610 & 6.72 & .014 \\
\hline Error & 36 & 537 & $\ldots$ & $\ldots$ \\
\hline
\end{tabular}

rapidly expanding competitive dominant and maintain higher plant diversity in the upper marsh.

\section{Acknowledgments}

We thank L. Rider for helpful comments and careful editing. W. Ferren of the University of California Santa Barbara Herbarium provided help with access to the field, funds, and plant identification. S.C.P. gratefully acknowledges funding from the National Institute for Global Environmental Change. This is contribution 841 from the University of Georgia Marine Institute.

\section{Literature Cited}

Berlow, E. L. 1999. Strong effects of weak interactions in ecological communities. Nature (London) 398:330-334. Bertness, M. D., and R. M. Callaway. 1994. Positive in- teractions in communities. Trends in Ecology \& Evolution 9:191-193.

Buss, L. W., and J. B. C. Jackson. 1979. Competitive networks: nontranstitive competitive relationships in cryptic coral reef environments. American Naturalist 113: 223-234.

Callaway, R. M. 1994. Facilitative and interfering effects of Arthrocnemum subterminale on winter annuals. Ecology 75:681-686.

. 1995. Positive interactions among plants. Botanical Review 61:306-349.

Callaway, R. M., and C. Sabraw. 1994. Effects of variable precipitation on the structure and diversity of a California salt marsh community. Journal of Vegetation Science 5:433-438.

Callaway, R. M., S. Jones, W. R. Ferren, and A. Parikh. 1990. Ecology of a Mediterranean-climate estuarine wet- 
land at Carpinteria, California: plant distributions and soil salinity. Canadian Journal of Botany 69:1139-1146.

Case, T. J. 1991. Invasion resistance, species build-up and community collapse in metapopulation models with interspecies competition. Biological Journal of the Linnean Society 42:239-266.

Connell, J. R. 1990. Apparent versus "real" competition in plants. Pages 9-26 in J. B. Grace and D. Tilman, eds. Perspectives on plant competition. Academic Press, New York.

Davidson, D. W. 1980. Some consequences of diffuse competition in a desert ant community. American Naturalist 116:92-105.

Ferren, W. R., Jr. 1985. Carpinteria Salt Marsh: environment, history, and botanical resources of a southern California salt marsh. The Herbarium, University of California, Santa Barbara, Calif. Publication 4.

Holzapfel, C., and B. E. Mahall. 1999. Bidirectional facilitation and interference between shrubs and annuals in the Mojave Desert. Ecology 80:1747-1761.

Kerfoot, W. C., and A. Sih. 1987. Predation: direct and indirect impacts on aquatic communities. University Press of New England, Hanover, N.H.

Lawlor, L. R. 1979. Direct and indirect effects of $n$-species competition. Oecologia (Berlin) 43:355-364.

Levine, J. M. 1999. Indirect facilitation: evidence and predictions from a riparian community. Ecology 80: 1762-1769.

Levine, S. H. 1976. Competitive interactions in ecosystems. American Naturalist 110:903-910.

Lubchenco, J. 1978. Plant species diversity in a marine intertidal community: the importance of herbivore food preference and algal competitive abilities. American Naturalist 112:23-39.

MacArthur, R. H. 1972. Geographical ecology. Harper \& Row, New York.

Miller, T. E. 1994. Direct and indirect species interactions in an early old-field plant community. American Naturalist 143:1007-1025.

Miller, T. E., and J. Travis. 1996. The evolutionary role of indirect effects in communities. Ecology 77:1329-1335. Moro, M. J., F. I. Pugnaire, P. Haase, and J. Puigdefabregas.
1997. Effect of the canopy of Retama sphaerocarpa on its understory in a semiarid environment. Functional Ecology 11:425-431.

Paine, R. T. 1966. Food web complexity and species diversity. American Naturalist 100:65-75.

Pennings, S. C., and R. M. Callaway. 1992. Salt marsh plant zonation: the relative importance of competition and physical factors. Ecology 73:681-690.

- 1996. Impact of a parasitic plant on the structure and dynamics of salt marsh vegetation. Ecology 77 : 1410-1419.

Petranka, J. W., and J. K. McPherson. 1979. The role of Rhus copallina in the dynamics of the forest-prairie ecotone in north-central Oklahoma. Ecology 60:956-965.

Pianka, E. R. 1974. Niche overlap and diffuse competition. Proceedings of the National Academy of Sciences of the USA 71:2141-2145.

Pugnaire, F. I., P. Haase, and J. Puigdefabregas. 1996. Facilitation between higher plant species in a semiarid environment. Ecology 77:1420-1426.

SPSS. 1997. SPSS. Version 7.5. SPSS Inc., Chicago.

Stone, L., and A. Roberts. 1991. Conditions for a species to gain advantage from the presence of competitors. Ecology 72:1964-1972.

Takahashi, K. 1997. Regeneration and coexistence of two subalpine conifer species in relation to dwarf bamboo in the understorey. Journal of Vegetation Science 8: 529-536.

Vandermeer, J. 1990. Indirect and diffuse interactions: complicated cycles in population embedded in a large community. Journal of Theoretical Biology 142:429-442.

Wilson, S. D., and P. A. Keddy. 1986a. Measuring diffuse competition along an environmental gradient: results from a shoreline plant community. American Naturalist 127:862-869.

- $1986 \mathrm{~b}$. Species competitive ability and position along a natural stress/disturbance gradient. Ecology 67: 1236-1242.

Wooton, J. T. 1994. The nature and consequences of indirect effects in ecological communities. Annual Review of Ecology and Systematics 25:443-466.

Associate Editor: Thomas E. Miller 